\title{
Association of two SNPs in the coding region of the insulin-like growth factor 1 receptor (IGF1R) gene with growth-related traits in Angus cattle
}

\author{
M. Szewczuk • S. Zych • J. Wójcik • E. \\ Czerniawska-Piątkowska
}

Received: 29 August 2012 / Revised: 27 December 2012 / Accepted: 27 May 2013 / Published online: 19 June 2013

(C) The Author(s) 2013. This article is published with open access at Springerlink.com

\begin{abstract}
The insulin-like growth factor 1 (IGF-1) is considered to be a factor that mainly regulates growth, differentiation, and the maintenance of various function in numerous tissues through binding to a family of transmembrane tyrosine kinase receptors, signaling primarily through the insulin-like growth factor 1 receptor (IGF-1R) encoded by the IGFIR gene. The objectives of the present study were to estimate the allele and genotype frequencies of the IGFIR/MspI (silent mutation within exon 12) and the IGFIR/TaqI (within the $3^{\prime}$ untranslated region, $3^{\prime} \mathrm{UTR}$ ) gene polymorphisms in beef cattle and to determine associations between these polymorphisms and growth traits. In a preliminary study on 310 Angus calves, association analyses with three production traits (birth weight, BWT; weaning weight adjusted to 210 days, $\mathrm{WWT}_{210}$; and average daily gain, ADG) were conducted. The $G G$ genotype of the IGFIR/e12/MspI polymorphism was significantly associated $(P \leq 0.05)$ with a higher $\mathrm{WWT}_{210}(+5.06 \mathrm{~kg})$ compared to the $A G$ genotype. Polymorphism within the 3'UTR had no significant effect on growth traits. The effect of combined genotypes was also examined. At $\mathrm{WWT}_{210}$, calves with the $G G / A A$ and $G G / A G$ combinations were heavier than calves with the $A G / A A$ and $A G / A G$ combined genotypes $(P \leq 0.05)$. To our knowledge, this is the first report of a polymorphism within the coding region of the Bos taurus IGFIR gene.
\end{abstract}

\footnotetext{
M. Szewczuk $(\bowtie) \cdot J$. Wójcik $\cdot$ E.

Czerniawska-Piątkowska

Laboratory of Molecular Cytogenetics, Department of Ruminant

Science, The West Pomeranian University of Technology, Judyma

10, 71-460 Szczecin, Poland

e-mail: malgorzata.szewczuk@zut.edu.pl

S. Zych

Laboratory of Veterinary Diagnostic "Labo-Wet", Pyrzycka 9A, 70-892 Szczecin, Poland
}

Keywords Beef · Genetic markers · IGF1R . Quantitative trait loci

The insulin-like growth factor (IGF) family includes three ligands, three cell membrane receptors, six binding proteins, and a number of other associated proteins. In mammals, insulin regulates cell metabolism, whereas insulin-like growth factor 1 (IGF-1) is an important regulator of cell growth (Ullrich et al. 1986). The majority of circulating IGF-1 is produced by the liver, where its expression is stimulated by growth hormone (GH). However, other organs can also produce IGF-1 in an autocrine and paracrine manner, including bovine mammary gland and muscle (Plath-Gabler et al. 2001). The insulin-like growth factor 1 receptor (IGF-1R) is a receptor-tyrosine kinase that plays a crucial role in signaling that is important for cell survival and proliferation. After binding to the primary ligand (IGF-1), signal cascade activates the phosphoinositide 3-kinase (PI3K), promotes cell proliferation by activating the mitogenactivated protein kinase (MAPK), and blocks apoptosis by inducing the phosphorylation and inhibition of proapoptotic proteins (Galvan et al. 2003).

In view of the important role of genes coding for components of the somatotropic axis (GH-GHR-IGF1-IGF1R) in growth regulation, the objectives of the present study were to estimate the allele and genotype frequencies of the two SNPs (rs41640706 and rs41960562) within the coding sequence of the bovine IGFIR gene in beef cattle and to determine the effects of these markers on growth traits in animals under an intensive production system. Both of these SNPs were submitted in the year 2006, but they have not been validated so far. The study involved 310 purebred Angus female calves of 54 sires kept in the years 2005-2010 on a single farm located in the West Pomeranian province, Poland. The DNA was isolated using the MasterPure ${ }^{\mathrm{TM}}$ DNA Purification Kit 
(Epicentre Technologies), according to the manufacturer's instructions.

The first polymorphism, a silent transition in the third nucleotide in the codon coding for proline (CCㅍ $\rightarrow$ CC $\underline{\mathbf{G}})$, is localized within exon 12 of the Bos taurus $\overline{I G F 1 R}$ gene and is annotated as rs41640706 in the dbSNP database (http://www.ncbi.nlm.nih.gov/snp/). The MspI restriction endonuclease is able to recognize guanine at this position and, therefore, this SNP was identified using the polymerase chain reaction-restriction fragment length polymorphism (PCR-RFLP) method. To genotype the IGF1R/e12/MspI polymorphism, a pair of primers $\left(\mathrm{T}_{\mathrm{a}}=59.5^{\circ} \mathrm{C}\right.$; forward: $5^{\prime}$ ttcttgcctgtttcaattgttg-3'; reverse: $5^{\prime}$-ctcgacttgggatccatatttt-3') was used to amplify a 164-bp DNA fragment.

The second polymorphic site ( $r s 41960562 ; \mathrm{A}<->\mathrm{G}$ transition) is localized within the $3^{\prime}$ untranslated region (3'UTR) of the Bos taurus IGFIR gene. Due to the lack of commercial endonucleases that would be able to identify this SNP, the amplification-created restriction site (ACRS) (Haliassos et al. 1989) protocol was developed to introduce an artificial $T a q \mathrm{I}$ recognition site. The $T a q \mathrm{I}$ recognition site $(\mathrm{t} \downarrow \operatorname{cg} \underline{\mathbf{a}})$ was engineered by enforcing a base change within a new front primer by replacing $\mathrm{T}$ with $\mathrm{C}\left(\mathrm{T}_{\mathrm{a}}=62{ }^{\circ} \mathrm{C}\right.$; forward: $5^{\prime}$ gccggtcaccataggtctC $\mathrm{Cg}-3^{\prime}$; reverse: $5^{\prime}$-agtgggggtttggcagaat3'; mismatch is underlined). A 163-bp DNA fragment was then amplified.

PCR was carried out in a total volume of $20 \mu$ containing 60-80 ng of DNA template, $0.5 \mathrm{U}$ of Taq DNA polymerase, buffer with $\left(\mathrm{NH}_{4}\right)_{2} \mathrm{SO}_{4}, \mathrm{MgCl}_{2}, \quad$ dNTP mix (MBI Fermentas/ABO, Gdansk, Poland), 10 pmol of each primer (Oligo, IBB PAN, Warsaw), and nuclease-free deionized water (Epicentre Technologies ${ }^{\mathrm{TM}}$, AKOR Gdansk, Poland). The reaction conditions were as follows: an initial DNA template denaturation at $94{ }^{\circ} \mathrm{C}$ for $5 \mathrm{~min}$, followed by 33 cycles of: denaturation of DNA template at $94^{\circ} \mathrm{C}$ for $50 \mathrm{~s}$, annealing $\left(\mathrm{T}_{\mathrm{a}}\right)$ at $59.5^{\circ} \mathrm{C}$ or $62{ }^{\circ} \mathrm{C}$ for $50 \mathrm{~s}$, extension at $72^{\circ} \mathrm{C}$ for $50 \mathrm{~s}$, and the final elongation at $72{ }^{\circ} \mathrm{C}$ for $7 \mathrm{~min}$ in the Biometra TPersonal ${ }^{\mathrm{TM}}$ thermal cycler (Biometra, Goettingen, Germany). Two specific PCR products were obtained. The 164-bp fragment was digested with 5 units of the $M s p I$ endonuclease $(10 \mathrm{U} / \mu \mathrm{l}$, $\mathrm{C} \downarrow$ CGG; MBI Fermentas/ABO, Gdansk, Poland) at $37{ }^{\circ} \mathrm{C}$ for $3 \mathrm{~h}$. In the case of the 163-bp fragment, the PCR product was digested for $2 \mathrm{~h}$ at $65{ }^{\circ} \mathrm{C}$ with 5 units of the TaqI restriction

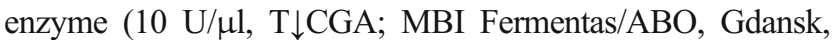
Poland). After digestion, $10 \mu \mathrm{l}$ of each of the products was then separated by electrophoresis in $2 \%$ ethidium bromidestained agarose gels (Basica Prona ${ }^{\mathrm{TM}}$ Agarose, $\mathrm{ABO}$, Gdansk, Poland).

The association of birth weight (BWT), weaning weight adjusted to 210 days of age (WWT ${ }_{210}$ ), as well as average daily gains between birth and weaning (ADG), with the selected SNPs within the bovine IGFIR gene was analyzed based on the data obtained from the official recordings.
Statistical calculations were performed using a general linear model (GLM) incorporated in the procedure of the STATISTICA 9.0 PL software package (StatSoft, Inc. 2009). The following statistical model was used:

$Y_{i j k l}=\mu+G_{i}+s_{j}+B Y S_{k}+e_{i j k l}$

where $Y_{i j k l}$ is the analyzed trait, $\mu$ the overall mean, $G_{i}$ the fixed effect of the IGF1R genotype or combination of genotypes $(i=1, \ldots 2$, or $1, \ldots, 4), s_{j}$ the random effect of the sire $(j=1, \ldots, 43), B Y S_{k}$ the fixed effect of the year/season of birth $(k=1, \ldots, 16)$ and $e_{i j k l}$ is the random error.

The 164-bp fragment amplified to identify rs41640706 SNP contained a single $M s p$ I recognition site. The digestion resulted in two fragments (51 and $113 \mathrm{bp}$ ) in the case of the $I G F 1 R^{\mathrm{G}}$ allele and one uncut 164-bp-long fragment carrying the $I G F 1 R^{\mathrm{A}}$ allele (Fig. 1). The $G G$ genotype had the highest frequency (0.593), followed by the $A G$ genotype $(0.371)$. The least frequent genotype was $A A$ ( $n=11$, only $3.6 \%$ of the analyzed population). The frequency of the rare $I G F I R^{\mathrm{A}}$ allele was 0.22 .

The 3'UTR PCR product carrying the rs41960562 polymorphism was cleaved by TaqI in the presence of the $I G F 1 R^{\mathrm{A}}$ allele into two fragments of $145 \mathrm{bp}$ and $18 \mathrm{bp}$; when the $I G F 1 R^{\mathrm{G}}$ allele was present, no cleavage was observed (163 bp) (Fig. 1). Among the 310 calves that were genotyped for this polymorphism, 196 (63.2\%) were of the $A A$ genotype, $95(30.7 \%)$ were of the $A G$ genotype, and only 19 individuals $(6.1 \%)$ possessed the $G G$ genotype (allele $I G F 1 R^{\mathrm{A}}: 79 \%$; IGF1R $\left.{ }^{\mathrm{G}}: 21 \%\right)$.

Table 1 shows the effect of the RFLP-MspI and ACRS$T a q \mathrm{I}$ polymorphisms in the IGFIR gene on growth performance. The $I G F 1 R / \mathrm{e} 12 / M s p \mathrm{I}$ polymorphism had a significant effect only on $\mathrm{WWT}_{210}(P \leq 0.05)$. The $G G$ genotype was associated with a higher $\mathrm{WWT}_{210}(+5.06 \mathrm{~kg})$ when

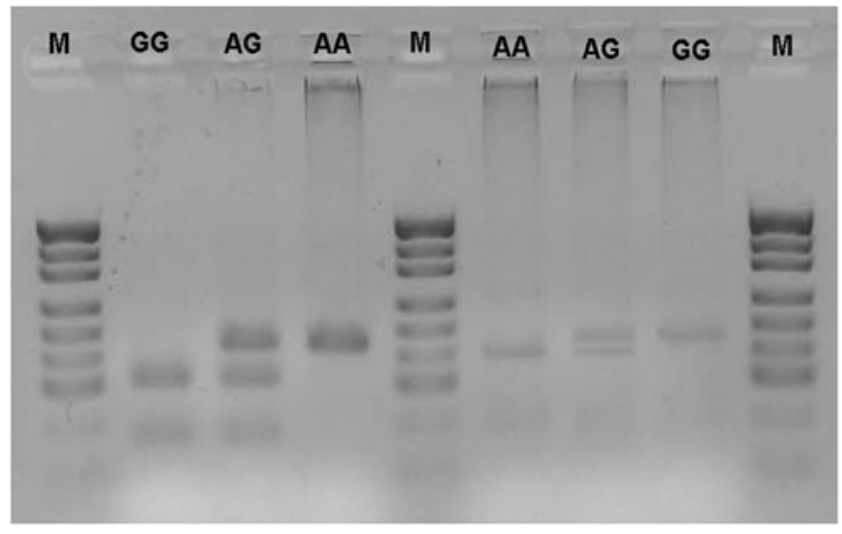

Fig. 1 Ethidium bromide-stained PCR products after digestion and gel electrophoresis. Lanes 1, 5, and 9: $M$, the DNA length marker pUC19/ $M s p I$. Lanes 2-4: the $I G F 1 R / \mathrm{e} 12 / M s p I$ polymorphism. Lanes 6-8: the $I G F 1 R / 3^{\prime} \mathrm{UTR} / \mathrm{TaqI}$ polymorphism (the small 18-bp fragment is not visible in the gel) 
Table 1 Mean values of growth traits of Angus cows with the different $I G F 1 R$ gene variants (standard errors in parentheses)

\begin{tabular}{lllllll}
\hline SNP & $\begin{array}{l}\text { Genotype or combined } \\
\text { genotype }\end{array}$ & $n$ & $f$ & BWT (kg) & ADG (g) & WWT $210(\mathrm{~kg})$ \\
\hline IGF1R/MspI & $G G$ & 184 & 0.593 & $36.49(0.23)$ & $994.5(4.9)$ & $247.61^{\mathrm{a}}(1.45)$ \\
& $A G$ & 115 & 0.371 & $36.88(0.32)$ & $984.7(7.0)$ & $242.55^{\mathrm{a}}(1.77)$ \\
IGF1R/TaqI & $A A$ & 196 & 0.632 & $36.68(0.22)$ & $988.6(4.8)$ & $245.84(1.42)$ \\
& $A G$ & 95 & 0.307 & $36.80(0.34)$ & $994.9(7.7)$ & $246.31(2.13)$ \\
IGF1R MspI/TaqI & $G G / A A$ & 109 & 0.352 & $36.46(0.28)$ & $993.6(6.2)$ & $247.98^{\mathrm{ab}}(1.91)$ \\
& $G G / A G$ & 60 & 0.193 & $36.67(0.44)$ & $1000.7(9.5)$ & $248.13^{\text {cd }}(2.68)$ \\
& $A G / A A$ & 78 & 0.252 & $36.97(0.37)$ & $982.8(8.3)$ & $242.59^{\mathrm{ac}}(2.22)$ \\
& $A G / A G$ & 34 & 0.110 & $37.09(0.56)$ & $982.1(13.0)$ & $241.18^{\text {bd }}(2.93)$ \\
\hline
\end{tabular}

Values within columns bearing the same letters differ significantly at $P \leq 0.05$

$n$ number of animals in the group; $f$ frequency; $B W T$ birth weight; $A D G$ average daily gains between birth and weaning; $W W T_{210}$ weaning weight adjusted to 210 days of age

compared to the $A G$ genotype. Because of the low number of $A A$ individuals, this genotype group was excluded from the association study. In the case of the polymorphism within the 3'UTR, no significant differences were observed when a small genotype group of $G G$ individuals was omitted.

The relatively high frequencies of the $G G(I G F 1 R / M s p \mathrm{I})$, $A A(I G F 1 R / T a q \mathrm{I})$, and heterozygous genotypes enabled analysis of the association between their combinations (as combined genotypes) and growth performance. The model was similar to that of a single-marker association analysis, except that the interaction between the two SNPs was included as a fixed effect. A total of four combinations showed a frequency higher than 0.1 (Table 1). Due to the low number of individuals in the groups, five rare combinations $(G G / G G$, $n=15 ; A A / A A, n=9 ; A G / G G, n=3 ; A A / A G, n=1$; and $A A / G G, n=1)$ were excluded from further analysis. The means for all the analyzed traits are given in Table 1, including a comparison of their combinations. As shown, the $G G / A A$ and $G G / A G$ combined genotypes were associated with superior growth trait in regard to $\mathrm{WWT}_{210}$. Calves carrying the above-mentioned combinations were heavier than calves with the $A G / A A$ and $A G / A G$ combined genotypes $(P \leq 0.05)$. The association analysis suggested that no significant differences were detected between the combined genotypes and BWT and ADG.

The bovine IGF1R gene was mapped to chromosome 21 (Moody et al. 1996). It consists of at least 21 exons encoding 1367 aa of unprocessed protein chain, including a 30-residue signal peptide. Like in humans, gene and protein organization is structurally related to the insulin receptor (Ullrich et al. 1986). Davis et al. (1998) and Casas et al. (2003) reported significant quantitative trait loci (QTL) for birth weight in the centromeric region of BTA21. The most significant QTL was at 4 centimorgans $(\mathrm{cM})$ from the beginning of the linkage group on chromosome 21 . Therefore, the gene(s) of interest should be located in the candidate region up to $10 \mathrm{cM}$. With respect to this criterion, we have identified several genes located in the candidate region, based on the Bos_taurus_UMD_3.1/Btau_4.6.1 genome assemblies (http://www.ncbi.nlm.nih.gov/assembly/; RefSeqID AC_ 000178.1/NC_007319.5). One of the most promising candidates is the $I G F 1 R$ gene (relative position: $8.278 \mathrm{cM}$ ), closely related to $I G F 1$, located in the QTL for birth weight on BTA5 (Kim et al. 2003).

Little is known about the associations between the polymorphisms within the bovine IGFIR gene and meat production traits. The IGFIR/TaqI polymorphism within intron 12, detected originally by Moody et al. (1996), seems to be exclusive to Bos indicus. To date, very few data are available regarding the effect of this polymorphism on growth and carcass traits in Bos indicus (Curi et al. 2005) and Chinese indigenous beef cattle (Zhang and Li 2011).

In the present study, we described a novel protocol to detect silent mutation within exon 12 (rs41640706; GenBank accession no. JQ924783) that does not affect the protein sequence. The proline- $807^{+30}$ residue is localized exactly in the middle of the extracellular sequence of the IGF-1R $\beta$ subunit (residues 711 to 905 upstream from the transmembrane domain; amino acids of the pro-receptor are numbered starting at Glu 1, preceded by a 30-residue signal peptide). The second polymorphic site, annotated as rs41960562 (see also GenBank accession no. JQ957797), is one of the several SNPs detected within the long $3^{\prime}$ UTR (exon 21) and, therefore, it is not related to the amino acid substitution either. However, point mutations within the $3^{\prime}$ UTR can be associated with the determination of mRNA stability/instability and, in special cases, with diseases. MicroRNAs (miRNAs) function post-transcriptionally by base-pairing to the mRNA 3'UTRs to repress protein synthesis by mechanisms that have not yet been fully understood. Current evidence suggests that the target mRNA degradation provides a major contribution to silencing by miRNAs (Huntzinger and Izaurralde 2011). To evaluate the 
potential role of the aforementioned SNP, we compared the nucleotide sequences of a full-length IGFIR 3'UTR (about $6.75 \mathrm{~kb}$ ) of several species (incl. Bos taurus, Homo sapiens, Mus musculus, and Rattus norvegicus; TargetScanHuman rel. 6.2; http://www.targetscan.org/), and then the location of the JQ957797 sequence with the rs41960562 SNP was established. A total of 66 miRNAs families conserved only among mammals were used to predict the biological targets of these miRNAs by searching for the presence of conserved 8- and 7mer sites within the $3^{\prime}$ UTR regions that would match the seed region of each miRNA (Lewis et al. 2005). The results did not indicate the presence of any conserved miRNAs overlapping the rs41960562 polymorphism. The nearest miRNA 7-mer (bta-miR-328) was located just 80-bp downstream.

The somatotropic axis contains the most promising candidate genes associated with meat production traits. Based on the knowledge of the polygenetic control of the studied physiological processes, we agree that further studies investigating the functional biology of the bovine IGF1R gene are necessary, in order to be able to consider the polymorphisms studied in this work as the causative mutations.

Acknowledgments This work was supported by the Ministry of Science and Higher Education (grant no. N N311 221738/2009). All procedures were approved by the Local Ethics Commission, permission no. 25/09.

Open Access This article is distributed under the terms of the Creative Commons Attribution License which permits any use, distribution, and reproduction in any medium, provided the original author(s) and the source are credited.

\section{References}

Casas E, Shackelford SD, Keele JW, Koohmaraie M, Smith TPL, Stone RT (2003) Detection of quantitative trait loci for growth and carcass composition in cattle. J Anim Sci 81:2976-2983
Curi RA, Oliveira HN, Silveira AC, Lopes CR (2005) Association between IGF-I, IGF-IR and GHRH gene polymorphisms and growth and carcass traits in beef cattle. Livest Prod Sci 94:159167

Davis GP, Hetzel DJS, Corbet NJ, Scacheri S, Lowden S, Renaud J, Mayne C, Stevenson R, Moore SS, Byrne K (1998) The mapping of QTL for birth weight in a tropical beef herd. In: Proceedings of the 6th World Congress on Genetics Applied to Livestock Production, Armidale, NSW, Australia, January 1998, vol 26, pp 441-444

Galvan V, Logvinova A, Sperandio S, Ichijo H, Bredesen DE (2003) Type 1 insulin-like growth factor receptor (IGF-IR) signaling inhibits apoptosis signal-regulating kinase 1 (ASK1). J Biol Chem 278:13325-13332

Haliassos A, Chomel JC, Tesson L, Baudis M, Kruh J, Kaplan JC, Kitzis A (1989) Modification of enzymatically amplified DNA for the detection of point mutations. Nucleic Acids Res 17:3606

Huntzinger E, Izaurralde E (2011) Gene silencing by microRNAs: contributions of translational repression and mRNA decay. Nat Rev Genet 12:99-110

Kim JJ, Farnir F, Savell J, Taylor JF (2003) Detection of quantitative trait loci for growth and beef carcass fatness traits in a cross between Bos taurus (Angus) and Bos indicus (Brahman) cattle. J Anim Sci 81:1933-1942

Lewis BP, Burge CB, Bartel DP (2005) Conserved seed pairing, often flanked by adenosines, indicates that thousands of human genes are microRNA targets. Cell 120:15-20

Moody DE, Pomp D, Barendse W (1996) Linkage mapping of the bovine insulin-like growth factor-1 receptor gene. Mamm Genome 7:168-169

Plath-Gabler A, Gabler C, Sinowatz F, Berisha B, Schams D (2001) The expression of the IGF family and $\mathrm{GH}$ receptor in the bovine mammary gland. J Endocrinol 168:39-48

StatSoft, Inc.: STATISTICA (data analysis software system) 2009, version 9.0 PL. http://www.statsoft.com

Ullrich A, Gray A, Tam AW, Yang-Feng T, Tsubokawa M, Collins C, Henzel W, Le Bon T, Kathuria S, Chen E, Jacobs S, Francke U, Ramachandran J, Fujita-Yamaguchi Y (1986) Insulin-like growth factor I receptor primary structure: comparison with insulin receptor suggests structural determinants that define functional specificity. EMBO J 5:2503-2512

Zhang R, Li X (2011) Association between IGF-IR, m-calpain and $U C P-3$ gene polymorphisms and growth traits in Nanyang cattle. Mol Biol Rep 38:2179-2184 